Newfoundland and Labrador Studies

\title{
The Commission of Government's 1944 Reconstruction Plan
}

\section{Melvin Baker and Peter Neary}

Volume 36, Number 1, 2021

URI: https://id.erudit.org/iderudit/1082215ar

DOI: https://doi.org/10.7202/1082215ar

See table of contents

Publisher(s)

Faculty of Arts, Memorial University

ISSN

1719-1726 (print)

$1715-1430$ (digital)

Explore this journal

Cite this document

Baker, M. \& Neary, P. (2021). The Commission of Government's 1944

Reconstruction Plan. Newfoundland and Labrador Studies, 36(1), 116-129.

https://doi.org/10.7202/1082215ar viewed online.

https://apropos.erudit.org/en/users/policy-on-use/ 


\section{The Commission of Government's 1944 Reconstruction Plan}

Melvin Baker and Peter Neary

On 16 February 1934, a British-appointed Commission of Government - forced on Newfoundland by the financial reverse of the Great Depression - took office in St. John's. The thinking behind the Commission was to give Newfoundland "a rest from politics," thereby setting the country on the financial straight and narrow and, eventually, a return to elective self-government. ${ }^{1}$ Under the first schedule of the United Kingdom act establishing the Commission, self-government would be restored when the country was "self-supporting" again and "on request" from the people, but no definition was given to "self-supporting" and no procedure was spelled out for the requisite request to be made. ${ }^{2}$

In its first years in office the Commission, supported by annual grants-in-aid from the United Kingdom, introduced various ameliorative social and economic reforms, but by 1936 it was already clear that deep-seated problems required more drastic action and long-term planning. In December 1936, at the request of the Secretary of State for Dominion Affairs in London, to whom it reported, the Commission submitted, in 97 paragraphs, a detailed reconstruction plan for Newfoundland. ${ }^{3}$ When this was overtaken by the so-called Roosevelt Recession, which hit the North American economy soon thereafter, the Commission opted for an experiment - the brainchild of Commissioner 
for Natural Resources John H. Gorvin (1886-1960) — in root and branch reform of the fishing economy, the employment mainstay of the island. ${ }^{4}$ But the coming of war in 1939 - and, thanks to Canadian and American base building, an unprecedented prosperity that followed allowed the Commission to bury this potentially explosive initiative. ${ }^{5} \mathrm{By}$ 1942, with Newfoundland enjoying full employment and now loaning Canadian dollars to London, the United Kingdom recognized that constitutional change would soon be necessary. In September 1942 United Kingdom Deputy Prime Minister Clement Attlee (1883-1967), Secretary of State for Dominion Affairs, visited Newfoundland and in 1943 a British parliamentary mission toured the country. ${ }^{6}$ In December 1943 the British government publicly promised that at the end of the war in Europe, Newfoundlanders would be empowered to decide their own constitutional future - but through means decided on in London. ${ }^{7}$

In the wake of this announcement, planning began within the United Kingdom government for a possible return of self-government to Newfoundland. Believing that Newfoundland might face the return of stiff economic headwinds in the post-war period, the Dominions Office initially favoured the introduction of a further reconstruction plan, to be funded by London, as a prelude to the return of self-government to Newfoundland, albeit with financial strings attached. ${ }^{8}$ On 25 September 1944, at the request of Dominion Affairs Secretary Lord Cranborne (1893-1972) ${ }^{9}$ and after complex negotiations, the Commission submitted the plan envisaged; it was to run for 10 years and cost $\$ 100$ million. Governor Sir Humphrey T. Walwyn's covering despatch and an attached summary of the projects to be undertaken are printed below with editorial changes shown in square brackets. ${ }^{10} \mathrm{Wal}-$ wyn's despatch was accompanied by four lengthy, detailed appendices (A-D, not printed here), which are a rich source for understanding the social and economic condition of Newfoundland at the time and prefigured much that would happen there in the 1950s.

The Commission's plan met a cold reception at the Treasury in London, with resident advisor John Maynard Keynes (1883-1946) wondering whether $\$ 100$ million was "a misprint for $\$ 10$ million." 11 
"Even if we were stuffed with money," the eminent economist cautioned, "this would seem to be somewhat out of proportion." Given the financial reality now facing their own country, the British changed course: the reconstruction plan was filed away and instead priority was given to promoting the cause of Confederation with Canada - a long-standing Whitehall goal for Newfoundland - in the constitutional round that would follow the war. In 1946, London approved a modified reconstruction program for Newfoundland, intended to tide the Commission over until the constitutional issue was settled. ${ }^{12}$ De facto, the British achieved their objective when, on 22 July 1948, in the second of two referendums, Newfoundlanders voted in favour of "Confederation with Canada" over "Responsible Government as it existed in 1933."13 Immediately before the end of March 1949, Newfoundland became a province of Canada and the Commission of Government faded into history, leaving behind it both plans and senior civil servants who knew how to plan.

\section{Document}

\section{NEWFOUNDLAND}

No. 237 (Top Secret)

Government House

St. John's

September 25th 1944

My Lord,

I have the honour to refer to your Telegram No. 502 Top Secret, of the 13th September, and previous correspondence, including your Secret Despatch No. 135 of the 7th June, regarding the completion by the Commission of Government of a long-term reconstruction programme to be financed over a period of ten years out of funds to be provided by the Government of the United Kingdom. 
2. The Commission of Government has now prepared the outline of a reconstruction programme designed as the best means of promoting the economic and social development of the Island. In the preparation of the programme the Commission has been guided by the advice given by Your Lordship in the correspondence referred to, supplemented by the views expressed in oral discussion with members of the Commission who have recently visited London. ${ }^{14}$ The outline reconstruction programme is contained in Appendices to this despatch, which are preceded by a summary showing the estimated expenditure under various headings. The total sum requested to implement this programme, inclusive of an amount of \$10,500,000 earmarked in Appendix A for Supplementary Schemes and Contingencies, is $\$ 100,000,000$.

3. As your Lordship is aware, the Commission of Government has for some time been engaged in the preparation of plans for longterm reconstruction, and proposals relating to the Fisheries, Agriculture and Land Development have already been submitted for your approval, while outlines of schemes for the improvement of roads and breakwaters, education and medical services have been communicated to you semi-officially. We wish to make it clear that the latter schemes, and indeed the great majority of the plans for which provision is made in the comprehensive programme now submitted to you, will require study in much greater detail than has yet been possible before they can be put into operation. In some cases the figures quoted represent no more than suggested allocations of amounts which in the opinion of the Commission might reasonably be expended on the objects stated and rest on the assumption that it will still be possible at a later stage to prepare satisfactory schemes in detail. The programme as a whole must be regarded as flexible and provisional, and subject to adjustment or modifications as experience and circumstances dictate.

4. In preparing its outline programme the Commission has had regard to the total amount which Your Lordship has indicated might be placed at the disposal of the Government of Newfoundland as a Development Fund; it has endeavoured within this limit to meet the more urgent needs of the Island, giving due consideration to the 
importance of making adequate provision for economic development so as to increase the earning power of the country and provide a more stable foundation for improved standards of living and social services. The Commission has experienced particular difficulty in framing plans for industrial and economic development other than those relating to the Fisheries and the Land. There is no means of ascertaining in advance the extent to which private enterprise within the Island is prepared to play its part in sharing in the extensive investment of new capital which is essential to a successful reorganization of the Island's economy. Nor is there any possibility at this juncture of assessing the probable amount of outside capital which can be attracted for the development of new industries. The sums included in the programme under the heading of Economic Development, which amount to $\$ 39,600,000$ (Appendix A), represent the maximum provision which the Commission feels it can justify under this Head in the light of the information at present in its possession. Included in this amount is an unallocated reserve of $\$ 10,500,000$, which it is felt may be required as development proceeds. It will be noted that no less than $\$ 6,000,000$ has been earmarked for exploration, research and experiments which in most cases must precede actual industrial development. At the same time, I should point out that a considerable portion of the $\$ 30,000,000$ allotted to Improvement of Communications (Appendix B) may be regarded as being of a somewhat similar character to schemes for Economic Development, since the services to be provided will materially assist industrial expansion.

5. In providing for Social Services the Commission has been conscious of the inadequate level of many present services and of the entire absence of others which are greatly needed. The field for improvement under this Head is extremely wide, and for the purpose of the reconstruction programme it has been necessary to select the improvements which in the opinion of the Commission are most needed. The Commission hopes that it may be found possible to effect additional improvements in social and welfare and other services, not included in the reconstruction programme, out of the general revenues of the Island. 
6. The Commission has found it almost impossible to allot an order of priority, based on relative importance, to the schemes contained in the programme; it has felt compelled to effect a balance between the various needs of the Island, both economic and social. Should it be necessary to reduce the total provision, the Commission would prefer to have an opportunity of reviewing the programme as a whole.

7. So far as the time factor is concerned, industrial development will, as already mentioned, depend to a considerable extent on the progress and success of investigation and experiment. In the case of communications, and buildings (which also form a considerable part of schemes for social development), the rate of progress will be determined to a great extent by the availability of qualified labour and materials, as well as by the capacity of the administrative machinery. In all fields the rate of progress will depend a great deal on ability to obtain professional and technical assistance for the services concerned.

8. The figures shown in the summary to the Appendices relate to capital expenditure, or to expenditure on special reconstruction services which could be allowed to lapse at the end of the 10 year period. The cost of annual maintenance of new services or the additional annual maintenance cost of expanded services, which will continue after the reconstruction period, and for which provision must be made in addition to the capital or special expenditure shown in the summary, is estimated to amount to $\$ 2,700,000$, under the following heads:

Economic Development Schemes

Fishery Research

Improvement of Communications

Roads

Breakwaters

200,000

Social Improvement Schemes

Educational \& Library Services

Health \& Welfare

$$
900,000
$$

$\$ 2,700,000$ 
It is not expected that this annual total will be reached before the end of the 10 year period. The average annual cost throughout this period will probably be no more than half this amount. The total cost of Road Maintenance is expected to reach approximately $\$ 2,000,000$ p.a., ${ }^{15}$ roughly twice the amount actually spent at the present time. With regard to Breakwaters and Wharves, it is assumed that, in continuation of the policy now advocated, annual maintenance will remain at an average of $\$ 300,000$ after the ten year period, compared to the present inadequate level of approximately $\$ 100,000$. No provision has been made for recurring costs of maintenance of Air Bases, ${ }^{16}$ as the future position in regard to Newfoundland's responsibility for such undertaking is not yet sufficiently clear.

9. It will be observed that in some instances, e.g. in the programme outlined for Fishery Research and the Building of Vessels under Appendix A, expenditure which it is proposed to meet from the Development Fund may lead to countervailing receipts. Recoveries may be expected also in the case of assistance for Housing Schemes (Appen$\operatorname{dix} \mathrm{C}$ ), if advances are made by way of loan. In the preparation of the present programme it has been assumed that receipts from such sources will be available, if required, to finance further approved development schemes, or alternatively to supplement the special maintenance fund which it is proposed to establish out of debt charges saved through the release of Newfoundland from her liability for the guaranteed Stock. ${ }^{17}$

10. I have already referred in paragraph 5 above to the possibility of providing for other improvements in existing services out of the general revenue of the Island. This will depend largely on the postwar economic position and resulting revenue capacity. The Commission is of opinion that, while it lasts, the work provided by the 10 year programme of the kind now envisaged will of itself have a markedly beneficial effect on the economy of the Island, and that if there is no serious recession in existing industries a fairly high general level of employment may well be the outcome. In view of the factual and objective survey of the financial and economic situation which is to be undertaken in the near future by officials from the United Kingdom, 
we do not propose to submit to you at this stage a forecast of the possible postwar financial position. ${ }^{18}$ It may be mentioned, however, that while certain of the capital expenditure now provided in the annual Estimates under the Head of "Reconstruction Expenditure" will disappear to the extent that provision is made in the programme to be financed by the Government of the United Kingdom, a considerable proportion of the services at present classified under "Reconstruction" headings have been excluded from the new programme on the ground that they have become more or less recurring services which will continue to be financed out of general revenue.

11. It will be observed that while a sum of $\$ 6,000,000$ has been allocated in Appendix C for assistance to Housing Schemes in other large centres of population, nothing has been included in respect of the scheme administered by the St. John's Housing Corporation, Government participation in which has already received your approval. The Commission has in mind that advances in respect of this scheme should be made out of general revenues or out of the revenue surplus, now amounting to $\$ 20,000,000$, which has been accumulated during the last four years. Should, however, heavy calls on this surplus make it desirable that the Government should borrow from the public amounts to be advanced by way of loan to the Corporation to finance the building of houses (owing to the present inability of the Newfoundland Government to guarantee direct borrowing by the Corporation), the Commission assumes that the consent of your Lordship would not be withheld from Government borrowing for this specific purpose.

12. The Commission has always regarded the accumulated surplus as being available primarily for the resettlement of men returned from War service, and to provide a reserve to meet special difficulties which are likely to arise during the period of adjustment following the termination of the War. It was at one time suggested that Government assistance towards the reorganization of the Fisheries and the cost of schemes for Land Development should be met out of this surplus, but provision for these services has now been included in the comprehensive reconstruction programme submitted with this despatch. The 
Commission feels that the calls on this reserve will still be considerable, and that it will prove to be of the greatest value during the reconstruction period in ensuring the continuation of new services already maintained out of general revenue, in providing for normal expansion, and to some extent in enabling much needed improvements to be effected in services for social welfare, which have not been considered appropriate for inclusion in the reconstruction programme.

13. I have the honour to request your approval in principle of the outline reconstruction programme contained in the annexed Appendices. The Commission of Government has been gratified to learn that it is not your intention that there should be any publication of the programme in its present form, and that the forthcoming announcement to Parliament will be restricted to a statement on general lines. In accordance with the request contained in your Telegram No. 502, of the 13th September, I have already forwarded to you by separate despatch the suggestions of the Commission for modification of the document "C" appended to Your Lordship's Paper entitled "Sequence of Events". 19

I have the honour to be,

My Lord,

Your Lordship's most obedient,

humble servant,

\section{HUMPHREY WALWYN}

\section{Governor.}




\section{SUMMARY OF OUTLINE RECONSTRUCTION PROGRAMME COVERING A PERIOD OF TEN YEARS}

Reference to Appendix

A. Economic Development Schemes

(i) The Fisheries -
(a) Research and experiments
$2,000,000$
(b) Vessels
$2,500,000$
(c) Participation in enterprises
$\underline{5,000,000}$
$\$ 9,500,000$

(ii) The Land -
(a) Research, experiments and developments
$2,000,000$
(b) Settling people on the land
$5,800,000$
(c) Geodetic Surveys and Aerial Photography
$\underline{1,300,000}$
$\$ 9,100,000$

(iii) The Forests -

(a) Research, experiments and forestry operations $\$ 1,000,000$

(iv) Industries -
(a) Research and experiments
$1,000,000$
(b) Participation in enterprises
$\underline{5,000,000}$
$\$ 6,000,000$

(v) The Minerals -

(a) Exploration and research in Newfoundland and Labrador

$1,000,000$

(vi) The Tourist Trade-

$2,500,000$

(vii) Supplementary Schemes for Economic

Development and Contingencies

$\underline{10,500,000}$

[Total, Economic Development Schemes]

$\$ 39,600,000$ 
B. Improvement of Communications

(i) Roads and Bridges $16,000,000$

(ii) Wharves, Breakwaters, etc. $2,000,000$

(iii) Railway equipment and facilities

(including dock and steamer services)

$6,000,000$

(iv) Participation in an Air Service $5,000,000$

(v) Telegraphs and Telephones $1,000,000$

[Total, Improvement of Communications]

$\$ 30,000,000$

C. Social Improvement Schemes

(i) Educational

Building and equipping -

(a) Schools

$5,000,000$

(b) Regional (High) Schools

$1,500,000$

(c) Vocational Institutes

750,000

(d) University (extension of University

Memorial College) and Hostels

750,000

(e) Playgrounds and Athletic Equipment

$\underline{500,000}$

$\$ 8,500,000$

(ii) Library Services

(a) Central Library (St. John's)

300,000

(b) Regional libraries

$\underline{100,000}$

$\$ 400,000$

(iii) Health and Welfare

Building and equipping hospitals, etc.

$7,400,000$

(iv) Housing

Assistance for housing schemes in the larger centres of population (exclusive of St. John's)

$5,000,000$

(v) Local Government

Development of Municipal Institutions

$\underline{5,000,000}$

[Total, Social Improvement Schemes]

$\$ 26,300,000$ 
D. Government Buildings (not included elsewhere)

(i) Central Government and Departmental Buildings $2,000,000$

(ii) Outport Government and Departmental Buildings 500,000

(iii) Three Fire Halls in St. John's, and certain shops, garages, warehouses, etc. for various Departments 450,000

(iv) Six Bait Depots and additions to Demonstration Farm buildings 250,000

(v) Penitentiary — remodelling original building and second new wing 200,000

(vi) Houses and quarters for Government servants $\underline{700,000}$ [Total, Government Buildings] $\$ 4,100,000$ TOTAL $\$ 100,000,000$

We are grateful to Jock Bates of Victoria, British Columbia, for editorial advice and assistance.

\section{Notes}

1 For the quotation, see United Kingdom, Cmd. 4480, Newfoundland Royal Commission 1933 Report, 195.

2 For the legislation, see United Kingdom, The Public General Acts, 1933-34, 5-14.

3 Peter Neary, "The Commission of Government on Reconstruction, December 1936," Newfoundland and Labrador Studies 26, no. 2 (2011): 151-98.

4 See Peter Neary, Newfoundland in the North Atlantic World, 1929-1949 (Montreal and Kingston: McGill-Queen's University Press, 1988), 96-104.

5 Ibid, 124-26.

6 Ibid., 176-77, 216-18. 
7 See https://api.parliament.uk/historic-hansard/commons/1943/ dec/02/dominion-affairs\#S5CV0395P0_19431202_HOC_383.

8 Neary, Newfoundland in the North Atlantic World, 221-24.

9 From 1947 the fifth Marquess of Salisbury.

10 The archival reference is The Rooms Provincial Archives (RPA), St. John's, GN1/3/A, box 258, file 8, "Newfoundland Affairs - Ten Year Programme," despatch 8/44. See also United Kingdom National Archives, DO 35/1342/N402/29 (available on microfilm, boxes 5258 and 5259, at RPA). Walwyn (1879-1957) had been Governor of Newfoundland since 1936.

11 Neary, Newfoundland in the North Atlantic World, 228.

12 Ibid, 243-49.

13 Ibid., 323.

14 Commissioner for Natural Resources P.D.H. Dunn (1892-1965), Commissioner for Justice and Defence L.E. Emerson (1890-1949), and Commissioner for Health and Welfare John C. Puddester (1881-1947); see Neary, Newfoundland in the North Atlantic World, 223-25. Under the Commission system, three Commissioners were drawn from the United Kingdom and three from Newfoundland. Dunn was a United Kingdom Commissioner and Emerson and Puddester were Newfoundlanders.

15 Per annum.

16 At the time the Royal Canadian Air Force had bases, built by Canada during the war, at Torbay (near St. John's) and Goose Bay, Labrador. Since 1940 Canada had been operating the Newfoundland Airport at Gander on behalf of the Newfoundland government. In October 1944, Canada secured a 99-year lease to the Goose Bay airbase. United States bases in the country operated under the terms of the AngloAmerican Leased Bases Agreement of 27 March 1941.

17 In connection with the reconstruction plan, the United Kingdom would assume responsibility for Newfoundland's sterling debt (see Neary, Newfoundland in the North Atlantic World, 224).

18 This intention led eventually to the publication of Cmd. 6849, Report on the Financial and Economic Position of Nerwfoundland, 1946. Prepared by G.W. St. John Chadwick of the Dominions Office and Edgar Jones of the Treasury, this report informed the work of the National 
Convention elected in Newfoundland the same year to advise on constitutional choices to be put before the people by referendum.

19 For this document, see United Kingdom National Archives, DO 35/1342/N402/29 (available on microfilm, boxes 5258 and 5259, at RPA). See also Neary, Nerwfoundland in the North Atlantic World, 403, note 48 . 